\title{
Occurrence of functional single-lobed ovary in Cirrhinus mrigala (Hamilton, 1822) brood fish from Assam, India
}

\author{
B. K. Bhattacharjya ${ }^{1}$, B. J. Saud ${ }^{1}$, V. K. Verma $^{1}$, D. Debnath ${ }^{1 *}$, D. Kumar ${ }^{1}$, A. K. Yadav ${ }^{1}$, \\ S. Yengkokpam ${ }^{1}$, and U. K. Sarkar ${ }^{2}$ \\ ${ }^{1}$ ICAR-Central Inland Fisheries Research Institute, Regional Centre, HOUSEFED Complex, Dispur, Guwahati - 781006 \\ (Assam), INDIA \\ ${ }^{2}$ ICAR-Central Inland Fisheries Research Institute, Barrackpore, Kolkata - 700120 (West Bengal), INDIA \\ *Corresponding author. E-mail: dipesh.debnath@gmail.com
}

Received: November 11, 2016; Revised received: July 8, 2017; Accepted: November 8, 2017

\begin{abstract}
Occurrence of abnormally developed gonads in fish is rather more uncommon in freshwater fish than marine fish. It is therefore worthwhile to disseminate the information of occurrence of a single-lobed ovary in Cirrhinus mrigala brood fish as an abnormal phenomenon. During April 2011 to March 2013, around 500 brood fish samples of Indian major carps (Labeo rohita, Catla catla and C. mrigala) were collected from different government and private fish farms of Assam and Tripura located in the Northeast of India. Among them, one C. mrigala specimen measuring $41 \mathrm{~cm}$ in total length and $640 \mathrm{~g}$ in weight collected from Ulubari fish seed farm of Guwahati, Assam during June, 2012 was found to have a single-lobed ovary instead of the normal bilobed structure. The ovary occupied the entire body cavity and the majority of ova were round and translucent. The ovary contributed substantially to the total body weight with gonado-somatic index of 32.81 which was the highest among all the mrigal specimens examined. The study indicates possibility of artificially inducing development of single-lobed ovary in $C$. mrigala for achieving possible higher spawn outputs in induced breeding of the cultivable species.
\end{abstract}

Keywords: Abnormal ovary, Brood fish, Cirrhinus mrigala, Single-lobed ovaryary, Brood fish

\section{INTRODUCTION}

Fish reproduction is characterized by a puzzling diversity of strategies (in sharp contrast to the reproductive scheme of mammals, birds, most reptiles and amphibians) regarding how different species determine their sex, produce male $\&$ female fertile gametes and mate; however the ovary in most teleosts is a paired organ that is attached to the body cavity (Urbatzka et al., 2011). Gonadal abnormalities including hermaphroditism (i.e., presence of male and female reproductive organs in the same organism) have been observed in many marine fishes during 1950s and 60s. For example, hermaphroditism in marine fishes was observed by Chacko and Krishnamoorthy (1949) in Hilsa ilisha, Prabhu and Antony Raja (1959), Thomas and Raju (1964) in Rastrelliger canagurta, Nayak (1959) in Polynemus heptadactylus, Raju (1960) and Thomas and Raju (1964) in Katsuwonus pelamis, Rao (1962) in Rastrelliger canagurta. Some gonadal abnormalities were reported by Bensam $(1964,1968)$ and Dhulkhed (1966) in Sardinella longiceps. Lal Mohan (1970) came across several abnormalities in gonads of Pennahia aneus, a sciaenid fish, such as (i) ovary with a constriction on right lobe, (ii) ovary with partially atrophied left lobe, (iii) ovary with completely atrophied left lobe, (iv) testis with atrophied left lobe, (v) testis with completely atrophied right lobe and malformed left lobe and (vi) asexual gonad. Antony Raja and Bande (per. comm.) during early 70s reported yet another peculiar occurrence of an additional ripe lobe along with the normal pair of ovaries in Rastrelliger kanagurta. Therefore, it is evident that occurrence of abnormal ovaries and testes was mostly reported in marine fishes, and not in freshwater fishes. Cirrhinus mrigala is one of the major carps of India that is widely cultivated in freshwater ponds as bottom dwelling and detritivorous component under polyculture systems. It is a common and important food fish occurring in the Indian subcontinent including Pakistan, Nepal and Bhutan (Talwar and Jhingran, 1991). It contributes considerably to the inland fish production of the country both from capture fisheries of Ganga and Brahmaputra river systems as well as from pond aquaculture and fish stock enhancements in reservoirs and wetlands.

\section{MATERIALS AND METHODS}

Around 500 brood fish samples of Indian major carps (L. rohita, C. catla and C. mrigala) were collected from different government and private fish farms of Assam and Tripura located in the Northeast of India 
during April 2011 to March 2013. Identification of specimens was done following Talwar and Jhingran (1991). The collections were made on regular basis from those farms, and maturity, fecundity, gonado-somatic index and other parameters of reproductive biology including seasonal shifts of spawning behaviour were estimated/ inferred in the field and/or laboratory following standard methods and manuals (Biswas, 1993; Pradhan and Palekar, 1956).

\section{RESULTS AND DISCUSSION}

A single $C$. mrigala specimen (female) measuring 41 $\mathrm{cm}$ in total length and $640 \mathrm{~g}$ in weight was collected from Ulubari fish seed farm, Guwahati, India during June, 2012 had a single-lobed ovary (Fig. 1) instead of the normal bilobed structure (Lagler et al., 1962). The fish looked morphologically normal from external appearance and was in ripe condition at the time of observation. Although the ripe ova were not oozing out, they were found in the lumen; slight pressure at the posterior end extruded ova through the common oviduct opening. Upon dissection it was observed that the single-lobed ovary was positioned in the median longitudinal axis covering the entire body cavity of the fish. The ovary was found to be fully ripe with majority of' ova round and translucent. The weight of the ovary contributed substantially to the total body weight with calculated gonado-somatic index of 32.81, which was the highest among the 15 fully mature/ ripe female $C$. mrigala specimens examined on that particular sampling day (Table 1).
During the course of the past two years, over 250 female specimens of $C$. catla, L. rohita and C. mrigala were collected, which were found to be at various stages of ovarian development. The fact that only one of these specimens had single-lobed ovary suggested it to be a rare biological phenomenon. It was difficult to judge from the careful observations whether one of the ovaries of the specimen gradually degenerated in the course of its growth and maturation or it developed as a single-lobed ovary from the onset of its maturation process. Reports on fishes with abnormal ovary are few and usually limited to sporadically caught marine specimens, which were reported in 60's and 70's only. Raju (1960) and Thomas and Raju (1964) recorded some gonadal abnormalities in oceanic skipjack (Katsuwonus pelamis) and in the Indian mackerel (Rastrelliger kanagurta) from Indian marine waters. Desai and Rao (1971) observed a deceptive appearance of fully ripe $C$. mrigala female where the gonads were immature due to apparent fat deposition in the body.

A perusal of available scientific literature, mostly reported in the 1950s till 70s suggests that single-lobed ovary is unique in fishes since this condition failed to find a mention in the bibliography of anomalies in fishes (such as Dawson, 1964, 1966, 1971; Hickey, 1972; Dawson and Heal, 1976). The existing literature is silent on the exact cause of such ovarian abnormality. For example, Kraak et al. (1998) state that reproduction in fishes is dependent on the coordinated action of various hormones associated with the brainhypothalamus-pituitary-gonad axis; Fuzzen et al.

Table 1. Gonado-somatic index (GSI) and fecundity of female Cirrhinus mrigala .

\begin{tabular}{ccccccc}
\hline $\begin{array}{c}\text { Sl. } \\
\text { No. }\end{array}$ & $\begin{array}{c}\text { Length } \\
(\mathbf{c m})\end{array}$ & $\begin{array}{c}\text { Weight } \\
(\mathbf{g})\end{array}$ & $\begin{array}{c}\text { Weight of } \\
\text { gonad }(\mathbf{g})\end{array}$ & GSI & $\begin{array}{c}\text { Absolute } \\
\text { fecundity }\end{array}$ & $\begin{array}{c}\text { Relative } \\
\text { fecundity }\end{array}$ \\
\hline 1 & 37.4 & 500 & 42.0 & 8.4 & 55,692 & $1,11,384$ \\
2 & 41.5 & 615 & 49.0 & 7.96 & 56,693 & 92,183 \\
3 & 33.9 & 381 & 24.11 & 6.33 & 33,665 & 88,359 \\
4 & 37.6 & 500 & 47.86 & 9.57 & 88,426 & $1,76,853$ \\
5 & 33.9 & 370 & 44.58 & 12.05 & 59,860 & $2,38,989$ \\
6 & 39.1 & 560 & 71.03 & 12.68 & 56,858 & $1,06,893$ \\
7 & 34.8 & 430 & 78.37 & 18.23 & 71,204 & $1,65,590$ \\
8 & 36.0 & 400 & 53.23 & 13.31 & 53,020 & $1,32,550$ \\
9 & 27.0 & 226 & 29.41 & 13.01 & 27,206 & $1,20,380$ \\
10 & 27.5 & 228 & 30.18 & 13.24 & 47,592 & $2,08,737$ \\
11 & 32.0 & 400 & 88.21 & 22.05 & 51,957 & $1,29,892$ \\
12 & 28.0 & 218 & 31.08 & 14.26 & 25,455 & $1,16,766$ \\
13 & 40.7 & 863 & 140.0 & 16.22 & $1,08,780$ & $1,26,048$ \\
14 & 55.5 & 1569 & 101.0 & 6.44 & 68,680 & 43,773 \\
$15 *$ & 41.0 & 640 & 210.0 & 32.81 & $2,15,874$ & $3,37,303$ \\
\hline
\end{tabular}

*GSI of female Cirrhinus mrigala specimen with single-lobed ovary 

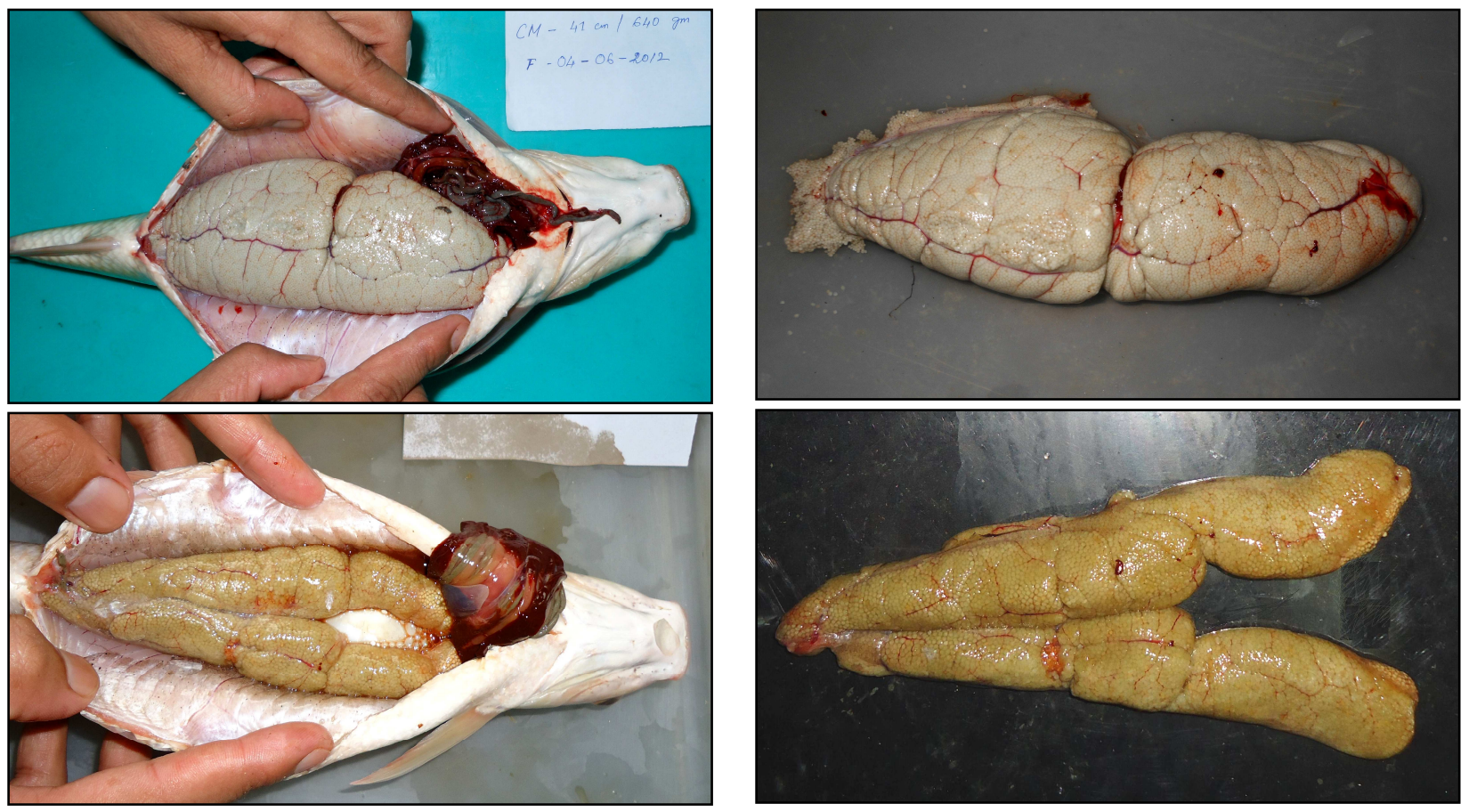

Fig. 1. Single-lobed ovary of C. mrigala ( A and B); a normal bilobed ovary of another C. mrigala female specimen dissected at the same time is also shown ( $\mathrm{C}$ and $\mathrm{D})$.

(2011) provide evidence that stress and activation of the hypothalamic-pituitary-interrenal axis affect reproduction in fish through actions on the central nervous system, pituitary, gonads and production of hepatic vitellogenin; but both the groups did not provide any examples of abnormal gonads in fish as reported in the present study. Hence, we assume that it could be due to interplay of one or several factors related to genetic disorders and physiological aberrations which in turn may be influenced by a number of environmental factors including water temperature, rainfall and availability of natural food. In the study area, there have been changes in temperature and rainfall patterns in recent years. Reduced rainfall and occasional high temperature spells during pre-monsoon season (MarchMay) obviously affected gonadal development of the Indian major carp species. Though the underlying principles of regulation of ovarian development seem to be evolutionarily conserved among species and within vertebrates, future research should focus on early stages of oocyte development, maintenance and fate of primordial germ cells and on their local recruitment, and mechanism governing oocyte atresia (Urbatzka et al., 2011). It was reported that females of some fish species kept in captivity or used in aquaculture production often experience reproductive failures or delayed maturation of germ cells (Mylonas and Zohar, 2001), but the reasons thereof are not known. Nevertheless the occurrence of a fully functional and ripe single-lobed ovary in C. mrigala contributing as much as $32.81 \%$ of body weight makes an interesting observation, for the first time in any of the Indian major carps.

\section{Conclusion}

Gonadal development is an important physiological phenomenon having a direct bearing on the breeding and recruitment process in fishes. In the present case, the development of single-lobed ovary in $C$. mrigala resulted in very high GSI values and relative fecundity. There is need for examining the possibility of artificially inducing development of single-lobed ovary in the species to see if it leads to higher spawn outputs in induced breeding of the cultivable species.

\section{ACKNOWLEDGMENTS}

Funding support received under NICRA project through ICAR-CRIDA, Hyderabad is duly acknowledged. We are grateful to Director, ICARCIFRI, Barrackpore for providing facilities and encouragement. We thank the Director of Fisheries, Govt. of Assam; District Fishery Development Officer, Kamrup, Guwahati and staff members of Ulubari Govt. fish seed farm, Guwahati and Director of Fisheries, Govt. of Tripura for providing brood stock specimens for the study.

\section{REFERENCES}

Bensam, P. (1964). On certain gonadial abnormalities met with in the Indian oil sardine Sardinella longlceps Valenciennes. J. Mar. Biol. Ass. India 6: 135-142.

Bensam, P. (1968). Further instance of gonadial peculiarities 
in Sardinella longiceps Valenciennes. J. Mar. Biol Ass. India 10: 172-173.

Biswas, S. P. (1993). Manual of methods in fish biology. South Asian Publishers Pvt. Ltd, New Delhi, India, 157 pp.

Chacko, P. I., Krishnamoorthy, B. (1949). Hermaphroditism in the Indian shad Hilsa ilisha (Hamilton). Proc. $36^{\text {th }}$ Indian Sci. Congr. Abst. 167 pp.

Dawson, C. E. (1964). A bibliography of anomalies in fishes. Gulf Res. Repts. 1: 308-399.

Dawson, C. E. (1966). A bibliography of anomalies in fishes. Gulf Res. Repts. Suppl.1, 2: 169-239.

Dawson, C. E. (1971). A bibliography of anomalies in fishes. Gulf Res. Repts. Suppl. 2, 3: 215-239.

Dawson, C. E., Heal, E. (1976). A bibliography of anomalies in fishes. Gulf Res. Repts. Suppl. 3, 5: 35-41.

Desai, V. R., Rao K. J. (1971). On the retardation of gonadial development due to excessive adiposity in Cirrhinus mrigala (Hamilton). J. Inland Fish. Soc. India 3: 125-126.

Dhulkhed, M. H. (1966). On an unusual ovary of the Indian oil sardine Sardinella longiceps Valenciennes. J. Mar. Biol. Ass. India 7: 210-212.

Fuzzen, M.L.M., Bernier, N.J. and Kraak, G.V.D. (2011). Stress and reproduction. In: Hormones and Reproduction of Vertebrates, Vol. 1 : Fishes (eds. Norris, D.O. and Lopez, K.H.), Academic Press, Elsevier, USA, pp. 103-117.

Hickey, C. R. (1972). Common abnormalities in fishes, their causes and effects. Technical Report No. 0013, New York Ocean Science Laboratory, pp. 11-15.

Kraak, G.V.D., Chang, J.P. and Janz, D.M. (1998). Reproduction. In: The Physiology of Fishes, $2^{\text {nd }}$ Edition (ed. Evans, D.H.), CRC Press, USA, pp. 465-488.

Lagler K. F., Bardach J. E., Miller R. R. (1962). Ichthyology.
Wiley International Edition, Wiley, New York.

Lal Mohan, R. S. (1970). Gonadial abnormalities in the sciaenid fish, Pennahia aneus (Bloch). J. Mar. Biol. Ass. India 12: 163-165.

Mylonas, C.C. and Zohar, Y. (2001). Use of GnRHa-delivery systems for the control of reproduction in fish. Rev. Fish Biol. Fish., 10: 463-491.

Nayak, P. D. (1959). Occurrence of hermaphroditism in Polynemus heptadactylus Cuvier \& Valenciennes. J. Mar. Biol. Ass. India 1: 257-258.

Prabhu, M. S., Antony Raja, B. T. (1959). An instance of hermaphroditism in Indian mackerel Rastrelliger canagurta (Cuvier). Curr. Sci. 23: 73-74.

Pradhan, L. B., Palekar V. C. (1956). Key to the stages of sexual maturity of Rastrelliger kanagurta. Indian $J$. Fish 3: 183-185.

Raju, G. (1960). A case of hermaphroditism and some other gonadial abnormalities in the skipjack Katsuwonus pelamis (Linnaeus). J. Mar. Biol. Ass. India 2: 95-102.

Rao, K. V. (1962). A note on a hermaphroditic gonad in the Indian mackerel Rastrelliger kanagurta (Cuvier). J. Mar. Biol. Ass. India 4: 241-243.

Talwar, P. K., Jhingran, A. G. (1991). Inland fishes of India and adjacent countries (Vols. 1\&2). Oxford and IBH Publishing Co. Pvt. Ltd., New Delhi, 1158 pp.

Thomas, P. T., Raju, G. (1964). Gonadial abnormalities in scombroid fishes. Proc. Symposium on Scombroid Fishes. Marine Biological Association of India, Mandapam Camp, pp. 719-724.

Urbatzka, R., Rocha, M.J. and Rocha, E. (2011). Regulation of ovarian development and function in teleosts. In: Hormones and Reproduction of Vertebrates, Vol. 1 : Fishes (eds. Norris, D.O. and Lopez, K.H.), Academic Press, Elsevier, USA, pp. 65-82. 